\title{
SUBMITTING FINANCIAL STATEMENTS OF ENTERPRISES IN XBRL
}

\author{
Proskurina N. M., Pushkar I. V., Plutytska K. M. \\ Zaporizhzhya National University \\ Ukraine, 69000, Zaporozhye, Zhukovsky St. 66 \\ profauditzp@ukr.net,iv_pushkar@ukr.net, viktoriakalinchuk@gmail.com \\ ORCID 0000-0001-8674-1720, ORCID 0000-0003-4380-7907, ORCID 0000-0002-0280-0453
}

Key words:

financial statements, notes to financial statements, disclosure, taxonomy, XBRL, validation.
Notes to the financial statements are an important source of economic and accounting information. The tendency to information overload of notes causes a rethinking of their role and content, as well as a revision of regulations governing the process of submitting financial statements at the legislative level. There is an urgent need to improve the disclosure process for disclosure requirements to prevent duplication of information in the financial statements as a whole and to eliminate irrelevant disclosures. This contributes to the fact that the information in the notes is clear, consistent, can be compared both in the dynamics of the enterprise and with the enterprises of the industry. The article examines the scientific approaches of domestic scientists on the architecture of notes to financial statements, which takes into account the relationship between the level of objectivity risk and the level of information risk. Starting in 2019, companies that are required to report under International Financial Reporting Standards are required to file taxonomic financial statements in a single electronic XBRL format. The main legislative acts regulating the use of this format are analyzed. The article considers the key principles of using the HBRL format. Based on the study of information resources, the elements of taxonomy are described in detail with an explanation of their functions. Describes the purpose and identifies the main benefits of reporting in XBRL format. The article clearly considers the submission of reports in XBRL-format on the example of reporting of agricultural enterprises, the feature of which is the application of IAS 41 "Agriculture". Namely, the main components of this format that need to be used are studied, as well as the sources of information for filling in the main blocks of notes according to this standard, taking into account industry specifics. It is determined that an important stage of reporting in XBRL-format is validation, which involves checking the compliance of the completed data. The article describes free resources for reading this format, as well as free software for the formation and validation of financial statements in XBRL-format. The need for training and retraining of specialists responsible for the process of preparing financial statements is emphasized.

\section{ПОДАННЯ ФІНАНСОВОЇ ЗВІТНОСТІ ПІДПРИЄМСТВ У ФОРМАТІ ХВRL}

\author{
Проскуріна Н. М., Пушкарь І. В, Плутицька К. М. \\ Запорізький національний університет \\ Україна, 69000, м. Запоріжжя, вул. Жуковського 66
}

Ключові слова:
фінансова звітність, примітки до
фінансової звітності, розкриття
інформації, таксономія, XBRL, валідація.
Важливим джерелом економічної та бухгалтерської інформації є примітки до фінансової звітності. Тенденція до інформаційного перевантаження приміток обумовлює переосмислення їх ролі та змісту, а також перегляд нормативних актів, якими регулюється процес подання фінансової звітності на законодавчому рівні. Постає актуальна необхідність у вдосконалення процесу формування приміток щодо встановлення вимог до розкриття, щоб запобігти дублюванню інформації у фінансовій звітності в цілому та елімінувати неактуальні розкриття. Це сприяє тому, що інформація у примітках $є$ зрозумілою, послідовною, може бути порівняна як у динаміці самого підприємства, так і з підприємствами галузі. У статті досліджено наукові підходи вітчизняних вчених про архітектоніку приміток до фінансової звітності, яка враховує зв'язок між рівнем ризику об'єктивності та рівнем інформаційного ризику. Починаючи з 2019 року підприємства, які повинні подавати звітність за Міжнародними стандартами фінансової звітності, зобов'язані подавати фінансову звітність на підставі таксономії у єдиному електронному форматі XBRL. Проаналізовано основні законодавчі акти якими регулюється застосування даного формату. У статті розглянуто ключові принципи застосування XBRL-формату. На підставі дослідження інформаційних ресурсів детально описано елементи таксономії з поясненням ïx функцій. Описано призначення та виявлені основні переваги звітування у форматі XBRL. У статті наглядно розглянуто подання звітності у XBRL- 
форматі на прикладі звітності сільськогосподарських підприємств, особливістю яких є застосування МСБО 41 «Сільське господарство». А саме досліджено основні компоненти даного формату, які необхідно застосовувати, а також розглянуто джерела інформації для заповнення основних блоків приміток за даним стандартом, враховуючи галузеві особливості. Визначено, що важливим етапом формування звітності у XBRL-форматі $€$ валідація, яка передбачає перевірку відповідності заповнених даних. У статті описано безкоштовні ресурси для ознайомлення 3 даним форматом, а також безкоштовне програмне забезпечення для формування та валідації фінансової звітності у XBRL-форматі. Підкреслено необхідність підготовки та підвищення кваліфікації фахівців, які відповідають за процес складання фінансової звітності.

\section{Statement of the problem}

The increase in the level of economic globalization and integration of capital markets has led to the development and implementation of a single international set of accounting standards, which are International Financial Reporting Standards (IFRS) and accounting, which will further eliminate economic and trade barriers, increase investment flows and open exits to world capital markets. However, the transition of Ukrainian enterprises to reporting under International Financial Reporting Standards creates certain difficulties due to the insufficient level of provision of methodological recommendations. Traditionally, the greatest difficulty for the compilers of IFRS financial statements is caused by the Notes to it. There is an objective need to develop methodological approaches to the logical construction and construction of Notes to IFRS financial statements separately for each industry, taking into account the specific features and standards used in specific industries. This will contribute to the orderly disclosure of information to users, the comparability of the Notes of different companies in the industry, improve the quality characteristics and transparency of financial statements in general.

\section{Analysis of recent researches and publications}

The process of compiling financial statements is a very important issue, which is covered in scientific papers. Харламова О.В. substantiated the appropriateness of building a hierarchical model of architecture Notes to IFRS financial statements, based on a logical structure "from objective to subjective" taking into account the level of information risk for users [1]. Marenich TG studied the formulation of basic approaches to the standardization of notes [2]. In the works of Akimova NS problems and prospects of international convergence of accounting standards are studied [3]. Highly appreciating the significant scientific and practical achievements of domestic scientists, a number of debatable aspects remain, as the requirements for the Notes to the financial statements in Ukraine are dynamic. There is a gradual process of integration of accounting methodology in accordance with the requirements of International Accounting and Reporting Standards. The method of preparation of financial statements of enterprises of public interest in XBRL format requires detailed consideration. As the requirement for such a format is enshrined in domestic legislation recently and comes into force for reporting in 2019 , there is an objective need to study the introduction of this method of reporting by domestic enterprises.

\section{Goals of the article}

The purpose of the article is to study the current problems of making notes to the financial statements and the specifics of reporting on the basis of taxonomy in a single electronic format XBRL.

\section{The main material of the research}

Today, with the adoption of new and amendments to existing financial reporting standards, such a component of reporting as notes is becoming increasingly important. Of particular relevance is the study of methodological and practical approaches to the logical construction and construction of Notes to IFRS financial statements. This topic is quite controversial and is studied in the scientific works of domestic scientists. Харламова О. В. argues that the architecture of the Notes to the financial statements should be based on a logical structure "from objective to subjective" and justifies the appropriateness of building a hierarchical model of the architecture of the Notes to IFRS financial statements based on this level, taking into account this level, risk for users (Table 1). Marenich TG believes that there is a conflict of interest in the preparation of notes for reporting: standardizers seek to meet the growing information requests of users and detail the requirements for information disclosure, and accountants form an unreasonably large amount of notes, which users can not understand. Therefore, the main criterion for the quality of notes to financial statements should be the balance between their brevity and excessively detailed data to be disclosed [2].

With the adoption of new and amendments to existing domestic legislation governing the submission of reports in Ukraine, namely the Law of Ukraine "On Accounting and Financial Reporting in Ukraine" of 16.07.1999 № 996-XIV [4] and Memorandum № 102 / 15 on mutual understanding on the development and implementation of financial reporting system [5], ends the period when the reporting of enterprises is full of standard disclosures, with inconsistent structure and does not have any logical structure in the disclosure of information. 
Table. 1 Architectonics notes to financial statements [6]

\begin{tabular}{|l|l|l|}
\hline \multicolumn{1}{|c|}{ Level of objectivity } & \multicolumn{1}{|c|}{ Components of notes to financial statements } & \multicolumn{1}{|c|}{ Level of information risk } \\
\hline The highest & $\begin{array}{l}\text { Basics of preparation, approval and submission } \\
\text { of financial statements }\end{array}$ & Almost absent \\
\hline High & Significant provisions of the accounting policy & Very low \\
\hline Not high & $\begin{array}{l}\text { Significant accounting judgments, estimates and } \\
\text { assumptions }\end{array}$ & Low \\
\hline Average & New standards & Average \\
\hline Low & $\begin{array}{l}\text { Reclassification of financial statements and } \\
\text { correction of errors }\end{array}$ & Not high \\
\hline Very low & $\begin{array}{l}\text { Disclosure of supporting information in the } \\
\text { financial statements }\end{array}$ & High \\
\hline Missing & Disclosure of other information & The highest \\
\hline
\end{tabular}

The current version of the Law of Ukraine «On Accounting and Financial Reporting in Ukraine» of 16.07.1999 № 996-XIV [4] has the concept of «taxonomy». Taxonomy of financial statements - the composition of articles and indicators of financial statements and its elements that are subject to disclosure. The taxonomy of financial statements is approved by the central executive body, which ensures the formation and implementation of state policy in the field of accounting. IFRS Taxonomy is a project under the auspices of the IFRS Committee, which systematizes and submits electronically the indicators to be disclosed in accordance with IFRS. In other words, it is an electronic reporting under IFRS. From a technical point of view, the taxonomy is based on XBRL - an open standard for presenting financial statements in electronic form. XBRL - eXtensible Business Reporting Language, which literally means "Extensible Business Reporting Language". The IFRS taxonomy improves communication between preparers and users of IFRS-compliant financial statements. In the process of preparing reports, elements of IFRS Taxonomy can be used to indicate the required disclosure, making them more accessible to users of electronic reports. The IFRS taxonomy reflects the requirements for the submission and disclosure of IFRS standards and includes elements from the accompanying materials to IFRS standards, such as guidance on implementation and illustrative examples. In addition, it contains disclosure elements that are not specifically required by IFRS, but are common in the practice of preparing financial statements.

We have considered the purpose and main benefits of reporting in XBRL format:

- flexible structure allows you to configure and apply different reporting scenarios (it is possible to display in the report only relevant information for the company, taking into account its specifics);

- this format is designed to describe and exchange related data with regulators, investors, between companies (includes all the necessary characteristics and functionality for this);

- unified format for all financial market regulators (National Commission on Securities and Stock Market, National Bank of Ukraine, Ministry of Finance of Ukraine, National Commission for State Regulation of Financial Services Markets);

- informativeness: exchange of aggregate data for analysis and decision-making, as it is compiled according to the same standards in one format, which simplifies the processing and analysis of such reports;

- communication of information: coding and decoding are built according to a certain syntax (grammar and semantics), coding languages are used in compilation, automation of filling reduces the complexity of the reporting process.

If the necessary resources are available, it is possible to configure the accounting database in XBRL format.

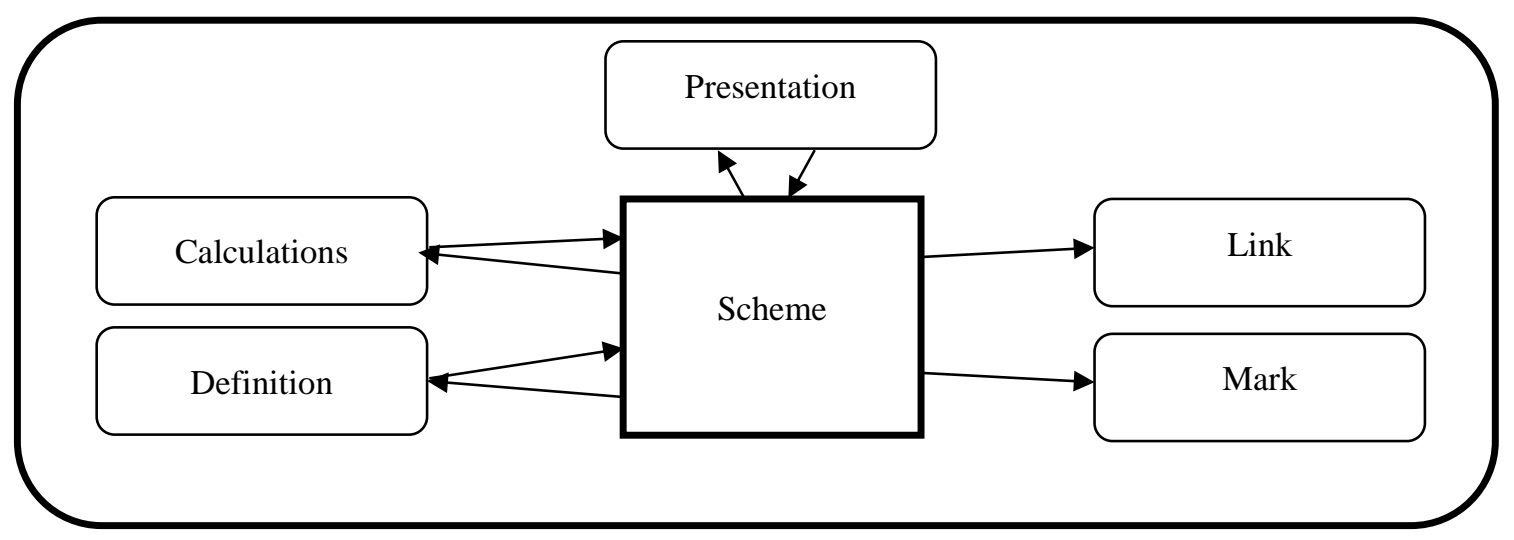

Fig. 1 The main elements of the presentation of XBRL-reporting (summarized by the authors based on [6]) 
We considered the scheme of application of XBRL-format in the preparation of reports, which is presented in Fig.1. The main components of this reporting format are the scheme, calculations, definitions, references, labels. The XBRL schema contains information about taxonomic elements. It can be thought of as a data repository that describes an unstructured list of elements and links to relationship database files. The submission relationship database stores information about the relationships between the elements in order to properly organize the content of the taxonomy. This allows you to properly organize the elements in the structure in order to represent a hierarchical relationship among specific business data. The calculation relationship database contains definitions of the basic verification rules that apply to all taxonomic reporting documents. The hierarchical base of settlement relationships sorts all elements of the financial type so that the elements of the lower level give in the sum, taking into account the possible operations of subtraction between them, the element of the higher level as a result of these operations. The definition relationship base allows taxonomy creators to identify different types of relationships between elements. There are four standards for the types of relationships that are supported within this database. The first of them is called "general - individual". Within its framework there are concepts of more general and specific meaning. The second available type of relationship is "essence - derived name". Using it, the creators of taxonomy can point out that the two concepts have the same meaning. The third standard type of relationship is called the "requiring-element". As the name suggests, it requires you to enter the value of one element when creating a report document if the value of another element is entered. The fourth type of relationship "homogeneous data - a set of data." It resembles the type of connection "essence - derived name", but applies to elements of the type "data set" (tuple). It connects two data sets that are equivalent in terms of definition (documentation from the label relationship database or links from the link relationship database), but are different in terms of XML, ie do not have identical content models, for example, contain various elements.

The elements defined in this taxonomy relate to specific terms and concepts explained in the standards. For this reason, a taxonomy is often accompanied by a reference relationship database, which shows the relationships between elements and external regulatory acts and standards in relation to the taxonomy. Reference relationships do not contain the full text of regulatory acts. Instead, they point to the basic documents by identifying their names and pointing to the relevant items and subitems [7]. Consider the components of the XBRL format on the example of reporting of agricultural enterprises, a feature of which is the application of IAS 41 "Agriculture" [8]. The taxonomy provides a hierarchy of IFRS standards, a disclosure format and a reference to the IFRS standard. The notes to IAS 41 Agriculture should generally be constructed in the format of text blocks and tables that include axes and components. As this standard takes into account the specifics of the industry, the key tables are "Disclosure of detailed information on biological assets", "Disclosure of information on agricultural products", "Disclosure of information on the coordination of changes in biological assets". The textual disclosures contain information on biological assets and a description of the nature of activities, agricultural products in the harvesting city and government grants related to biological assets, a description of non-financial indicators or estimated physical assets and agricultural output, a description of financial risk management. related to agricultural activities, as well as information on the valuation method, explanations of its choice and key assumptions. The specified information in the notes is entered according to the results of IFRS-inventory of biological assets and / or according to accounting data. In modern conditions, there is a question of automation of collection and processing of such information, as well as adaptation of data to XBRL-format.

To date, the use of this reporting format is not technically complex. Commercial programs for automation of reporting in XBRL format and its verification and validation have been developed. However, during the transition phase or in the absence of resources to purchase these programs, companies can use free resources, which are posted on the website of the National Commission for State Regulation of Financial Services Markets [9] with appropriate instructions for installation, configuration and use. There are two versions of such programs: for insurance companies and other companies. An important step in reporting in XBRL format, especially at the implementation stage, is validation. This is the process of verifying financial statements for compliance with the validation rules laid down in the UA XBRL Taxonomy IFRS using specialized software. There is also free Arelle software for validation, which can be downloaded from the company's website. This software is built into the iXBRL Tool's financial reporting software. After successful validation of financial statements, companies submit reports to the SPS (financial reporting system). The level of efficiency and sufficient objectivity of information disclosure in the Notes to the financial statements depends on the specialists of the company who are engaged in its preparation. To date, there are training programs for financial reporting professionals, such as: ACCA, DipIFR, CAP / CIPA. There are also training programs for XBRL reporting, which are conducted by educational centers of professional accounting organizations and audit companies. Announcements of such events are published on the Internet, in particular on the website of the SPS (financial reporting system). The need for training is dictated by modern management realities, and companies should pay due attention to this aspect, but we should not forget about the principle of "cost-benefit": the benefits derived from information should exceed the cost of its provision.

\section{Conclusions}

In the process of forming a market environment in Ukraine, the role of financial analysis is growing in order to substantiate the financial decisions of economic entities, securities market participants, including issuers, investors, investment intermediaries, stock exchanges. This exacerbates the need for reliable information on the areas of fundraising and reliability of issuers of securities, potential borrowers, partners, etc. in order to reduce uncertainty, reduce the impact of subjective factors and improve the quality of management and investment 
decisions. The most powerful source of information about the financial and economic activities of the enterprise is the financial statements, which reflect the state and dynamics of the enterprise. The role and importance of financial reporting in information support is determined by the degree of demand for information, which is formed by the management system. Only in compliance with all the requirements for financial reporting, users will be able to obtain all necessary information about the activities and financial condition of the enterprise. An analysis of the scientific and practical literature revealed that the Notes to the financial statements should begin with the disclosure of the most objective information and end with the most subjective. The hierarchical model of architecture proposed by domestic scientists of the Notes to the financial IFRS-reporting is based exclusively on the requirements of IFRS systematized and ordered by the author and does not provide additional load on compilers of IFRS-reporting. The article examines the changes to key laws and regulations governing the process of preparation and submission of financial statements. The main advantages of reporting in XBRL format, in our opinion, are flexible structure, the ability to exchange related data, a unified format, informativeness, communication of information. We considered the scheme of application of XBRL-format and its main components: scheme, calculations, definitions, references, labels.

The components of XBRL-format on the example of reporting of agricultural enterprises are considered. It is found that the notes to IAS 41 Agriculture should be constructed primarily in the format of text blocks and tables that include axes and components. The taxonomy provides all the necessary disclosures for enterprises in the industry, including the management of financial risks associated with agricultural activities, as well as information on the valuation method, explanations of its choice and key assumptions. It was found that the required information can be entered based on the results of the IFRS inventory of biological assets and / or accounting data. Given the urgency of the issue of automation of collection and processing of such information, the availability of free and commercial programs for the formation and validation of reporting in XBRL-format. Free resources are freely available on the website of the National Commission for State Regulation of Financial Services Markets [9] with appropriate instructions for installation, configuration and use. These programs can be used by financial reporting professionals, regulators, academics, and students to study and improve this reporting format. Businesses that are interested in the quality and objectivity of the information disclosed in the financial statements should review and improve the training of professionals involved in its preparation, and direct all necessary resources necessary for the preparation and verification of data (eg software). Thus, the disclosure of information in XBRL-format will contribute to the orderly disclosure of information to users, comparability of Notes of different companies, improving the quality characteristics and transparency of financial statements in general. Areas of further research are to find ways to improve and automate the process of filling out reports in XBRL-format, setting up accounting programs for this format.

\section{References}

1. Kharlamova O. V. (2015) Arkhitektonika Prymitok do MSFZ-zvitnosti [Architectonics Notes to IFRS reporting]. Business Inform, no. 8, pp. 188-193.

2. Marenych T.H. (2016) Problemy rozkryttia informatsii u prymitkakh do finansovoi zvitnosti [Problems of disclosure of information in the notes to the financial statements]. Actual problems of innovative economy, no. 1, pp. 54-59.

3. Akymova N.S. (2018) Mezhdunarodnaia konverhentsyia standartov bukhhalterskoho ucheta: problemy y perspektivy [International convergence of accounting standards: problems and prospects]. Skhidna yevropa: ekonomika, biznes ta upravlinnia [Eastern Europe: Economics, Business and Management], no. 4 (15), pp. 394-402.

4. Law of Ukraine "On Accounting and Financial Reporting in Ukraine", 16.07.1999 № 996-XIV. https://zakon.rada.gov.ua/laws/show/996-14.

5. Memorandum No. 102/15 on understanding on the development and implementation of the financial reporting system dated 18.12.2017. URL: https://zakon.rada.gov.ua/laws/show/v0102201-17.

6. The official website of the XBRL system (2019). URL: https://www.xbrl.org/.

7. Taxonomy: the basics of basics. URL: http://msfz.ligazakon.ua/en/magazine_article/FZZ00113.

8. International Financial Reporting Standards. https: //195.78.68.18/minfin/control/en/ublish/article?

9. IFRS taxonomy. National Commission for the State Regulation of Financial Services Markets. URL: https://www.nfp.gov.ua/en/Taksonomiia-MSFZ.html. 